\title{
FIELD ASSESSMENT OF THE COMPATIBILITY BETWEEN FIVE Bradyrhizobium Japonicum STRAINS WITH FOUR SOYBEAN CULTIVARS.
}

Kandil, B. A. A.

Soils, Water and Environ. Inst., Agric. Res. Center (ARC), Giza, Egypt.

\begin{abstract}
A field experiment was conducted in a clayey soil to study the effect of inoculation with five Bradyrhizobium japonica strains namely, (USDA110, USDA HH303, UK 3407, USDA 118 and ARC500) to four soybean cultivars differing markedly in morphological traits (Clark, Crawford, Giza35 and Mc-call) on nodulation, growth, yield and yield components. Results revealed that the most effective symbiosis (leading to nitrogen fixation and good seed and straw yields and protein content) was achieved by careful selection of the appropriate strain for each cultivar. Strain USD A110 was the most efficient strain in $\mathrm{N}_{2}$-fixation and in increasing seed and straw yields on each cultivar followed by USDA HH303, USDA 118, ARC 500 and UK 3407strains, respectively. The tested soybean cultivars were differed in their response to inoculation. The highest responses were reported by Clark followed by Giza 35, Crawford and Mc-call cultivars, respectively. Generally, soybean inoculation with any strain of $B$. japonicum gave high responses in all tested parameters compared to those due to uninoculated plants and amended with the recommended dose of nitrogen fertilizer.
\end{abstract}

Keywords: Bradyrhizobium japonicum, symbiotic $\mathrm{N}_{2}$ fixation, soybean cultivars, nodulation, N-content, crude protein and seed \& straw yields.

\section{INTRODUCTION}

Soybean is one of the most important leguminous crops. It has long been considered as one of the five scored grains on account of its exceptional food value. The grain of present day cultivars contains on average $40 \%$ protein that contains a dozen of amino-acids, which are essential for man and animals, notably lysine, tryptophane, methionine and cystine and $21 \%$ oil of excellent quality on dry weight basis.

The symbiotic association between legumes and rhizobia is the most important bio-catalytic link for the flow of atmosphere- $\mathrm{N}$ and the living world (Paau, 1989).

In order to hardness the potential benefit of rhizobial inoculation in commercial agriculture, the consistency of their performance must be improved. This requires researches in many diverse as those of biological systems, which involved complex interaction among the host, soils and their microbial inhabitants and environment. The formation of effective nodules is complex and highly regulated process that requires coordinated expression of number of genes in the bacterial symbiont and the host plant.

Soybean was introduced to Egypt in the 1960's but was not able to be produced in commercial scale until the1970's. Farmers grow it as a nonlegume rely on heavy $\mathrm{N}$-fertilization to obtain high yield (Nassib et al., 1983). 
Kandil, B. A. A.

Because soybean is a newly introduced crop, Egyptian soils are void of native Bradyrhizobium japonicum in contrast to the traditional food legume crops such faba beans, lentils and berseem clover as their native rhizobia are ubiquitous in Egyptian soils (Ghobrial et al.,1995).

In Egypt it is found that soybean yield is more than doubled when effectively inoculated by effective rhizobia strains. Douka et al. (1986) reported that soybean inoculation with specific rhizobia strain can save more than $\quad 200 \mathrm{~kg} \mathrm{~N} / \mathrm{ha}$. Many of the published reports showed that the relationship between soybean cultivars and Bradyrhizobium strain is one of the most important factors influencing biological $\mathrm{N}_{2}$-fixation (Schmidt et al, 1986 and Ghobrial et al., 1995).

Successful inoculation of soybean with Bradyrhizobia is one of the most important factors that determine the seed yield .The response of different soybean cultivars to inoculation with different effective strains of Bradyrhizobium japonicum may be variable. Some strains give good nodulation on a soybean cultivar, while other strains fail to form nodules.

The present work aims to study the compatibility of five Bradyrhizobium japonicum strains with four commercial soybean cultivars grown in Egyptian clayey soils. As well as to study the effect of inoculation with rhizobia on soybean morphological characters, straw and seed yields, seeds $\mathrm{N}$-content, protein content and nodulation status.

\section{MATERIALS AND METHODS}

\section{Bacterial strains:}

Five Bradyrhizobium japonica strains namely, (USDA110, USDA HH303, UK 3407, USDA 118 and ARC500) were supplied by Microbiology Dept, Soils, Water and Environ. Res. Inst., (ARC), Giza, Egypt. Bradyrhizobium strains were grown each separately in Yeast Extract Manitol (YEM) culture medium (Vinscent, 1970). Bradyrhizobium strains cultures were incubated at $28^{\circ} \mathrm{C}$ for three days on rotary shaker until early log phase of $10^{9}$ viable cell $\mathrm{mL}^{-1}$.

\section{Experimental Techniques:}

Preparation of inoculants:

Vermiculite supplemented with $10 \%$ Irish peat was packed in poly ethylene bags ( $300 \mathrm{~g}$ carrier per bag), then sealed and sterilized by Gamma irradiation $\left(5.0 \times 10^{6}\right.$ rads.). Bacterial culture was injected into sterilized vermiculite to satisfy $60 \%$ water holding capacity.

\section{Soybean genotypes:}

Soybean seeds of four commercial genotypes namely, (Clark, Crawford, Giza35 and Mc-call) were kindly provided by Legumes Res. Dept., Field Crops Res. Inst., (ARC), Giza, Egypt.

Field experimental layout:

A field experiment was carried out at Zarzoura Agric. Res. Station, Ittay El-Baroud, Behaira Governorate, during summer season 2004 to study the effect of inoculation with different Bradyrhizobium japonicum strains on 
nodulation, growth, yield and yield components of the four soybean genotypes. Physical and Chemical properties of experimental soil were determined according to Jackson (1973) and are presented in (Table 1).

The following treatments were conducted:

1-Uninoculation + recommended dose of nitrogen $(60 \mathrm{kgN} /$ fed. $)(100 \% \mathrm{~N})$.

2- Inoculation with Brady. Japonicum (USDA 110$)+15 \mathrm{~kg} \mathrm{~N} / \mathrm{fed}$. $(25 \% \mathrm{~N})$.

3- Inoculation with Brady. Japonicum (USDA HH303) $+15 \mathrm{~kg} \mathrm{~N} / \mathrm{fed}$. $(25 \% \mathrm{~N})$.

4- Inoculation with Brady. Japonicum (UK 3407$)+15 \mathrm{~kg} \mathrm{~N} / \mathrm{fed}$. $(25 \% \mathrm{~N})$.

5- Inoculation with Brady. Japonicum (USDA 118) $+15 \mathrm{~kg} \mathrm{~N} / \mathrm{fed} .(25 \% \mathrm{~N})$.

6- Inoculation with Brady. Japonicum (ARC 500$)+15 \mathrm{~kg} \mathrm{~N} / \mathrm{fed}$. $(25 \% \mathrm{~N})$.

Table (1): Chemical and mechanical analyses of soil used for the field experiment

\begin{tabular}{|c|c|}
\hline Properties & Value \\
\hline $\begin{array}{l}\text { Chemical analysis :- } \\
\left.\mathrm{E} . \mathrm{C} . \text { (dS/m at } 25^{\circ} \mathrm{C}\right)(\text { soil:water extract } 1: 5) \\
\mathrm{PH}(\text { soil:water suspention 1:5) } \\
\mathrm{CaCo}_{3} \\
\text { Total nitrogen \% } \\
\text { Organic matter \% } \\
\text { Organic carbon \% } \\
\mathrm{C} / \mathrm{N} \text { ratio } \\
\text { Soluble cations (meq/L):- } \\
\mathrm{Ca}^{++} \\
\mathrm{Mg}^{++} \\
\mathrm{Na}^{+} \\
\mathrm{K}^{+} \\
\text {Soluble anions(meq/L):- } \\
\mathrm{CO}^{--} \\
\mathrm{HCO}^{-} \\
\mathrm{Cl}^{-} \\
\text {SO4- } \\
\text { Mechanical analysis :- } \\
\text { Sand } \\
\text { Silt } \\
\mathrm{Clay}^{-} \\
\text {Texture }\end{array}$ & $\begin{array}{l}2.10 \\
4.90 \\
4.70 \\
0.06 \\
\\
N^{*} \\
0.00 \\
3.30 \\
1.40 \\
7.06\end{array}$ \\
\hline
\end{tabular}

${ }^{\star}$ Not Detected

Soybean genotypes seeds were individually inoculated with the tested B. japonicum strains at a rate of $300 \mathrm{~g} / 40 \mathrm{~kg}$ seed each using Arabic gum solution (16\%) as sticking agent.

A split plot design with three replications was used. Plot area was 7.2 $\mathrm{m}^{2}$. While the main plots included soybean genotypes and bio-fertilization treatments were assigned to sub plots. All treatments received calcium super phosphate $\left(15.5 \% \mathrm{P}_{2} \mathrm{O}_{5}\right)$ at rate $100 \mathrm{~kg} / \mathrm{fed}$. Nitrogen fertilizer in the form of urea $(46.5 \% \mathrm{~N})$ was used as a source of nitrogen.

Plant samples were uprooted after 60 days from cultivation to determine the number and dry weight of nodules, dry weight of shoots following oven 
drying at $70^{\circ} \mathrm{C}$ up to a constant dry weight and nitrogen content of shoots was determined according to the methods described by Page et al. (1982).

At harvest (120 days from sowing) ten soybean plants were randomly sampled form the second inner tow rows of each plot to determine the following parameters:

1- Plant height $(\mathrm{cm})$.

2- Number of tillers per plant.

3- Number of pods per plant.

4- 100-seeds weight $(\mathrm{g})$.

5- Crude protein content of seed according to (A.O.A.C., 1990).

The middle three rows of each plot with $3 \mathrm{~m}^{2}$ in area were harvested to determine the straw and seed yields (ton/feddan). The obtained data were subjected to the analysis of variance as described by Sendecor and Cochran (1980).

\section{RESULTS AND DISCUSSION}

Data in Table (2) showed that successful nodulation was achieved in all inoculation treatments due to all tested soybean cultivars.

Table (2): Number and dry weight of nodules of four soybean cultivars inoculated with different Bradyrhizobium japonicum strains after 60days of sowing

\begin{tabular}{|c|c|c|c|c|c|c|c|c|}
\hline Character & \multicolumn{4}{|c|}{ Number of nodules/plant } & \multicolumn{4}{|c|}{ Dry weight of nodules(mg/plant) } \\
\hline Treatments Soybean cultivars & Clark & Crawford & Giza 35 & Mc-call & Clark & Crawford & Giza 35 & Mc-call \\
\hline $\begin{array}{l}\text { Uninoculated+(control) } 100 \% \\
\text { nitrogen fertilizer }\end{array}$ & 4.000 & 6.000 & 7.000 & 5.000 & 44.000 & 66.000 & 77.000 & 55.000 \\
\hline $\begin{array}{l}\text { Inoculated with } \begin{array}{c}\text { Bradyrizobium } \\
\text { japonicum } \\
\text { fertilizer }\end{array} \\
\text { usda110 }+25 \% \text { nitrogen }\end{array}$ & 31.000 & 28.000 & 60.000 & 21.000 & 341.000 & 308.000 & 660.000 & 231.000 \\
\hline $\begin{array}{l}\text { Inoculated with Bradyrizobium } \\
\text { japonicum USDAHH } 303+25 \% \\
\text { nitrogen fertilizer }\end{array}$ & 22.000 & 19.000 & 38.000 & 25.000 & 242.000 & 209.000 & 413.000 & 275.000 \\
\hline $\begin{array}{l}\text { Inoculated with } \begin{array}{c}\text { Bradyrizobium } \\
\text { japonicumUK } 3407+25 \% \text { nitrogen } \\
\text { fertilizer }\end{array} \\
\end{array}$ & 16.000 & 13.000 & 19.000 & 11.000 & 167.000 & 143.000 & 209.000 & 121.000 \\
\hline $\begin{array}{l}\text { Inoculated with } \begin{array}{l}\text { Bradyrizobium } \\
\text { japonicum USDA118+25\% nitrogen } \\
\text { fertilizer }\end{array} \\
\end{array}$ & 33.000 & 17.000 & 31.000 & 13.000 & 363.000 & 133.333 & 304.333 & 198.000 \\
\hline $\begin{array}{lcr}\text { Inoculated } & \text { with } & \text { Bradyrizobium } \\
\text { japonicum } & \text { ARC500+25\% } & \text { nitrogen } \\
\text { fertilizer } & & \end{array}$ & 17.000 & 16.000 & 25.00 & 16.00 & 183.333 & 176.00 & 304.333 & 176.00 \\
\hline L.S.D. 0.05 & 12.1491 & 7.0179 & 11.5156 & 5.2351 & 133.4498 & 77.1692 & 132.1324 & 57.586 \\
\hline
\end{tabular}

Highly significant increases were obtained in number and dry weight of nodules for all soybean inoculated treatments. On the other hand only a few nodules were found in the uninoculated plants due to weak establishment of native Bradyrhizobium japonicum in Egyptian soils.

The highest increases of nodule number ranged from 366.7 (USDA110 $\mathrm{x}$ Crawford) to $757.1 \%$ (USDA $110 \times$ Giza 35) against the lowest increases of 300.0 (UK $3407 \times$ Clark) to $116.7 \%$ (UK $3407 \times$ Crawford).

Concerning B. japonicum strains, results showed that USDA 110 strain had the highest nodule numbers for all tested soybean cultivars compared to the other B. japonicum strains except for (USDA $118 \times$ Clark). 
The responses of all inoculation treatment in both soybean cultivars in dry weight of nodules gave similar results as those obtained by nodules numbers. These findings were in accordance with those obtained by Ghobrial et al. (2002) and Mehesen (2004).

The abovementioned results indicated a positive response to inoculation with strain USDA 110 being the superior strain with all tested cultivars.

Data in Table (3) presented the dry weight of shoot ( $\mathrm{g} / \mathrm{plant}$ ) and shoot $\mathrm{N}$-content (mg/plant). The dry weight of shoots increased significantly due to four soybean cultivars inoculated with different B.japonicum strains. The increases ranged between 31.00 (USDA $100 \times$ Clark) and $1.71 \%$ (UK $3407 \times$ Crawford) compared to those obtained by uninoculated ones and those supplemented with full nitrogen fertilizer dose. These results are in agreement with those obtained by Ghobrial et al. (2002) and Mehesen (2004).

Inoculation with $B$. japonicum USDA 110 had recorded the favorite shoot dry weight, since it gave the highest increases, while the lowest ones were due to inoculation with B.japonicum UK 3407 strain. On the other hand, the effectiveness of B.japonicum strains can be ranked in descending order as USDA 110, USDA HH 303, USDA 118, ARC 500 and finally UK 3407.

The inoculation of all tested soybean cultivars with $B$. japonicum USDA 110 strain gave the highest increases in shoot $\mathrm{N}$-content being in the range of 81.69 of Giza 35 to $46.61 \%$ of Crawford, but the lowest increment percentages were obtained by all tested soybean cultivars inoculated with $B$. japonicum UK 3407 strain, the increases ranged between 20.88 of Clark and $9.23 \%$ of Crawford compared to those obtained by the uninoculated plants and/or those received the recommended dose of nitrogen fertilizer.

Data in Table (4) presented the number of pods/plant and 100-seed weight $(\mathrm{g})$. Results revealed that irrespective of cultivars, inoculated plants with different B.japonicum strains gave higher responses compared to those uninoculated plants and/ or those fertilized with $100 \%$ nitrogen. All inoculated soybean cultivars gave the highest increases being in the range of 75.8 to $33.8 \%$ due to the inoculation with $B$. japonicum USDA 110 strain, while soybean cultivars inoculated with $B$. japonicum UK 3407 strain recorded the lowest increases being in the range of 17.20 to $5.9 \%$. 
Kandil, B. A. A.

T 3-4 
Same responses were obtained in 100-seed weight (g) due to soybean cultivars inoculation with different $B$. japonicum strains. However, the superior results were due to soybean cultivars inoculated with USDA 110 strain, but the worst were due to soybean cultivars inoculated with UK 3407.

Strain USDA 110 has been previously reported as the most effective strain in both $\mathrm{N}_{2}$ - fixation and increasing the yield of soybean (Moawad et al., 1988 a \& b).

On the other words, the efficient strain was USDA 110 followed by USDA HH 303, USDA 118, ARC 500 and UK 3407 strains.

Irrespective of soybean cultivars, data in Table (5) demonstrated that uninoculated plants and fertilized with $60 \mathrm{~kg} \mathrm{~N} / \mathrm{fed}$ recorded the lowest values of straw and seed yields due to all tested soybean cultivars. With respect to inoculation, the maximum increases in straw and seed yields were obtained by inoculation with USDA 110 followed by inoculation with USDA HH303, USDA 118, ARC 500 and UK 3407 in descending order.

Regarding the response of the tested soybean cultivars to inoculation, it was found that the highest straw and seed yields were due to inoculation with (USDA HH303 x Mc-call), which recorded increases of 15.0 and $19.7 \%$ in both yields, respectively.

Data in Table (5) showed that USDA 110 was the most effective strain in infecting most of the tested soybean cultivars followed by USDA HH303, USDA 118, ARC 500 and UK 3407.

The present results were as similar as those obtained by Dubey (1995), Luna and Planchon (1995) and Araujo et al. (1996).

The effect of inoculation with B.japonicum strains on soybean crude protein are given in Table (6). Results indicated that uninoculated plants and received $60 \mathrm{~kg} \mathrm{~N} / \mathrm{fed}$ recorded the lowest percentage of crude protein (22.820 to 23.127).

Generally, inoculated soybean cultivars amended with $15 \mathrm{~kg} \mathrm{~N} / \mathrm{fed}$ recorded significant increases in crude protein percentages as compared with uninoculated plants control. The highest increases of crude protein were in the range of 24.77(USDA 110x Giza 35)to 9.2\%(USDA HH 303x Mc-call), while the lowest ones of crude protein being 8.2 (UK $340 \times$ Clark) to $2.6 \%$ (UK 340 x Giza 35 and Mc-call). The soybean cultivar Mc-call gave the highest increase with USDA HH303, while soybean cultivar Crawford recorded the lowest increase with ARC 500.The soybean Clark gave the highest percentage increase of crude protein with USDA 118 against the lowest one with UK 3407.

The abovementioned data indicated that strain USDA 110 was the most efficient strain in $\mathrm{N}_{2}$ - fixation and in increasing straw and seed yields of the tested soybean cultivars followed by strains USDA HH303, USDA 118 and ARC 500, while UK 3407 was the least effective strain. Taking into account the low fertilizer recovery by plants, it is suggested that adapted cultivars, which were properly inoculated with effective strains of Bradyrhizobium japonicum can fix most of the nitrogen they need for high yields. This is of a great economic importance for crops with high nitrogenfixation efficiency, like inoculated soybeans, which can fix more than $200 \mathrm{~kg}$ N/ha (Douka et al., 1986). 
Kandil, B. A. A.

T5-6

1386 
J. Agric. Sci. Mansoura Univ., 32 (2), February, 2007 
However, the differ:rence between cultivars in symbiotic performance was not only due to the ability to nodulate, but also rather than to a much higher nodule-specific efficiency (Du Teau et al., 1986). In most cases, the reaction of cultivated plants to environmental factors is bounded up with genetic factors.

Many published reports classify soybean cultivars according to their response to the inoculation with different $B$. japonicum strains. Kandil (2003) and El-sawy et al. (2006) mentioned that the relationship between variety and Rhizobium strains is one of the most important factors influencing biological nitrogen fixation.

Lala and Tilak (2000) and El-Sawy et al. (2006) mentioned that symbiotic rhizobial association can meet the entire nitrogen requirement to legumes as the system can siphon out appreciable amount of nitrogen for the atmospheric reservoir and enrich the soil plant with this important but scarce nutrient.

Generally, this study came to a conclusion that it is advisable to inoculate the right $B$. japonicum to the exact and proper soybean cultivar. This is to ensure the highest seed yield with superior quality.

\section{REFFERENCES}

A.O.A.C. (1990). Official Methods of Analysis of the Association of Official Analysis Chemists, (K. Helrich, ed.), A. O. A. C.Inc.,15 th edition, Virginia, USA : 9-64.

Araujo, F. F. de, R. E. V. Munhoz, M. Hungria and F. F. De-Araujo (1996). Initial nodulation in seven French bean cultivars inoculated with two Rizobium strains. Pesquisa Agropecuaria Brasileira. 435-445.

Douka, C. E., A. E. Nychas and A. C. Xenoulis (1986). Nitrogen fixation in soybean as influenced by cultivar and Rhizobium strain differences. Biol. Fertil. Soils. 2:113-118.

Du Teau, N. M., R. G. Palmer and A. G. Atherly (1986). Fast-Growing Rhizobium fredii are poor nitrogen-fixation symbionts of soybean. Crop Sci., 26:884-889.

Dubey, S. K. (1995). Interaction between Bradyrizobium japonicum inoculants and soybean (Glycin max) cultivars. Indian Journal of plant physiology. 38 (1): 54-56.

El-Sawy, W. A., G. A. A. Mekhemar and B. A. A. Kandil (2006). Comparative assessment of growth and yield responses of two peanut genotypes to inoculation with Bradyrhizobium conjugated with cyanobacteria and rhizobacteria. Minufiya J. Agric. Res., 31(4):1031-1049.

Ghobrial, W. N., R. Y. Rizk, Fatma A. Sherif N. Estafanous (2002). Rhizobium-soybean symbiosis as affected by source and quality of water used in irrigation. J. Agric. Sci. Mansoura Univ., 27(8):56675677. 
Ghobrial, W. N. DawlatAbady, R. Y. Abdel-Kodoos and Hegazy (1995). Nitrogen fixation potential as affected by B.japonicum and soybean cultivars for maximizing soybean productivity. Annals Agric. Sci. Ain Shams Univ., Cairo. 40 (1): 117-128.

Jakson, M. L. (1973). Soil Chemical Analysis. Prentic-Hall of India private Limited, New Delhi, India.

Kandil, B. A. A. (2003). Studies on biofertilizers application in Egypt. Ph.D. Thesis. Fac. Agric., Ain Shams Univ., Egypt.

Lala Saxena, A. K. and K. V. B. R. Tilak (2000). Biofertilizers to augment soil fertility and crop production. ed. K. Prishna.

Luna, R. and C. Planchon (1995). Genotype x Bradyrizobium japonicum strain interactions in dinitrogen fixation and agronomic traits of soybean (Glycine maxL.Merril). Euphytica. 86 (2): 127-134.

Mehesen Ahlam, A. M. (2004). Studies on efficiency of some symbiotic $\mathrm{N}_{2}$-fixing bacteria in relation to their legume hosts. Ph.D. Thesis, Fac. Agric., Mansoura Univ., Egypt.

Moawad, H., S. M. S. Badr El-Din and M. A. Khalafallh (1988a). Field performance of three Rhizobium japonicum strains with two soybean cultivars. Egypt. J. Microbiol., 23 (1): 135-145.

Moawad, H., M. A. Khalafallah and S. M. S. Badr El-Din (1988b). Field assessment of the interaction between seven soybean cultivars and three Rhizobium japonicum strains. Egypt. J. Microbiol., 23 (2): 199-208.

Nassib, A. M., K. C. Gassman; M. Z. Hassan; M. H. Sherbeeny and S. T. Abdallah (1983). Irrigated soybean production in Egypt: past, present and future trends. Research Report. EMCIP publication No. 69, 1-15. Ministry of Agriculture, Cairo, Egypt.

Paau,A.S(1989). Improvement of Rhizobium inoculants. Appl. Environ. Microbiol., 55: 862-865.

Page, A. L., R. H. Miller and D. R. Keeney (1982). Methods of soil analysis, Part2:Chemical and microbiological properties. Second Edition, Am. Soc. Agron. Inc., Soil Sci. Am., 595- 624.

Schmidt, E. L., M. J. Zidwick and H. M. Abebe (1986). Bradyrizobium japonicum. Serocluster 123 and diversity among member isolates. Appl. Environ. Micobiol., 51(6):1212-1215.

Snedecor, G. W. and W. G. Cochran (1980). Statistical methods $7^{\text {th }}$ ed., lowa State Univ. Press, USA, 255-269.

Vincent, J. M. (1970)."A manual for the Practical Study of Root-Nodule Bacteria"I Handb.15.Blackwell Scientific Publications Oxford, U.k. 
Kandil, B. A. A.

التقييم الحقلى للتوافق بين خمس سلالات برادى ريزبيم جابونيكم مع أربعة أصناف

فول صويا

بلال عبد السميع أحمد قنديل

معهد بحوث الأراضى والمياه والبيئة ـ مركز البحوث الزراعية. الجيزة

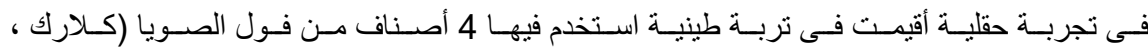

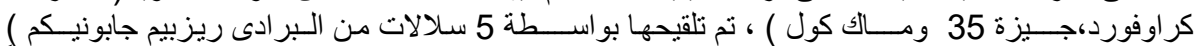

مقارنة ( USDA 110 , USDA HH303 , USDA118， ARC 500 and UK3407)

بمعاملة غير ملقحة ومزودة بالجرعة الموصى بها من السماد الأزوتى (60 كيلوجر ام أزوت / فدان).

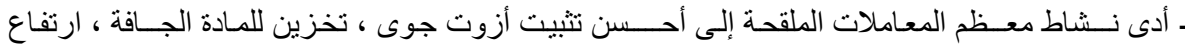

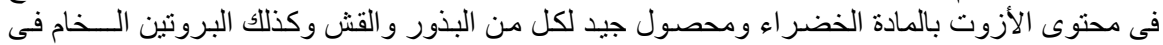

البذور مانو

ـ ـ وقد تم الحصول على هذه النتائج مع الــــــلالات المنو افقة مع كل صــــــف فول صويا منزرع ـ

ـ وقد كانت أكثر السلالات البكتيرية تو افقاً مع جميع أصناف فول الصويا هى السلالة (USDA 110)

تليها السـالات (USDA HH 303, USDA 118, ARC 500 and UK 3407) على الترتيب.

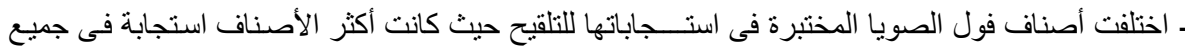

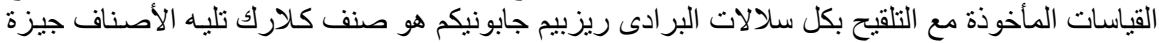

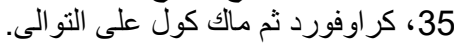

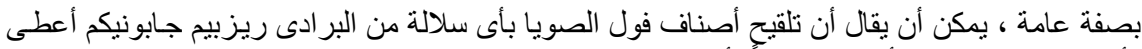

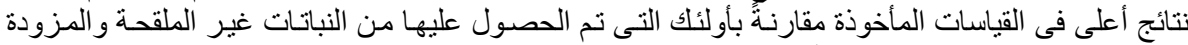

بالجر عة الموصى بها من السمادالأزونى (60 كيلو جرام / فدان). 
Table(6):Crud prote and nitrogen percentage in seeds of four soybean cultivars inoculated with different Bradyrhizobium japonicum strains at harvest stage(120 days from sowing)

\begin{tabular}{|c|c|c|c|c|c|c|c|c|}
\hline Character & Numbe & r of pods & /plant & & $100-\mathrm{se}$ & ed weigh & t (g) & \\
\hline $\mathrm{C}_{\text {Treatments }}^{\text {Soybean cultivars }}$ & Clark & Crawford & Giza35 & Mc-call & Clark & Crawford & Giza35 & Mc-call \\
\hline $\begin{array}{l}\text { Uninoculated+(control)100\% } \\
\text { Nitrogen fertilizer }\end{array}$ & 62.000 & 84.000 & 85.000 & 71.000 & 9.700 & 11.550 & 9.800 & 10.150 \\
\hline $\begin{array}{lll}\begin{array}{l}\text { Inoculated with } \\
\text { japonicum }\end{array} & \begin{array}{l}\text { Bradyrizobium } \\
\text { usda110+25\% }\end{array} \\
\text { nitrogen fertilizer } & \end{array}$ & 109.000 & 125.000 & 135.000 & 95.000 & 11.833 & 13.850 & 14.000 & 11.400 \\
\hline $\begin{array}{l}\text { Inoculated with Bradyrizobium } \\
\text { japonicum USDAHH303+25\% } \\
\text { Nitrogen fertilizer }\end{array}$ & 98.000 & 109.000 & 131.000 & 91.000 & 11.400 & 12.300 & 13.850 & 10.850 \\
\hline $\begin{array}{l}\text { Inoculated with Bradyrizobium } \\
\text { japonicumiUK3407+25\%nitrogen } \\
\text { fertilier }\end{array}$ & 72.667 & 89.000 & 94.000 & 79.000 & 9.883 & 11.600 & 11.850 & 10.500 \\
\hline $\begin{array}{l}\text { Inoculated with } \begin{array}{c}\text { Bradyrizobium } \\
\text { japonicum }\end{array} \text { USDA118+25\% } \\
\text { nitrogen fertilizer }\end{array}$ & 96.000 & 104.667 & 103.000 & 83.000 & 10.900 & 11.900 & 13.650 & 10.800 \\
\hline $\begin{array}{lll}\text { Inoculated with } & \text { Bradyrizobium } \\
\text { japonicum } & \text { ARC500+25\% } \\
\text { nitrogen fertilizer } & \end{array}$ & 92.000 & 97.000 & 100.000 & 82.000 & 10.567 & 11.600 & 12.600 & 10.650 \\
\hline L.S.D.0.05 & 22.1749 & 18.0422 & 20.5891 & N.S & 1.4174 & N.S & 2.1022 & N.S \\
\hline
\end{tabular}

Table (4): Number of pods and 100-seed weight of four soybean cultivars inoculated with different $B$. japonicum strains at harvest stage 
Kandil, B. A. A.

Table(3):dry weight and N-content of shoot of four soybean cultivars inoculated with different Bradyrhizobium japonicum strains

\begin{tabular}{|c|c|c|c|c|c|c|c|c|}
\hline \multirow{2}{*}{$\begin{array}{l}\text { Character } \\
\text { Treatments } \\
\text { Soybean cultivars }\end{array}$} & \multicolumn{4}{|c|}{ Straw yield (ton/fed) } & \multicolumn{4}{|c|}{ Seed yield (ton/fed) } \\
\hline & Clark & Crawford & Giza35 & $\begin{array}{l}\text { Mc- } \\
\text { call }\end{array}$ & Clark & Crawford & Giza35 & $\begin{array}{l}\text { Mc- } \\
\text { call }\end{array}$ \\
\hline $\begin{array}{l}\text { Uninoculated+(control) } 100 \% \\
\text { Nitrogen fertilizer }\end{array}$ & 3.100 & 3.460 & 2.980 & 1.530 & 1.215 & 1.280 & 1.480 & 0.660 \\
\hline $\begin{array}{ll}\text { Inoculated with } & \begin{array}{l}\text { Bradyrizobium } \\
\text { usda110+25\% }\end{array} \\
\text { japonicum } & \\
\text { nitrogen fertilizer } & \end{array}$ & 3.380 & 3.560 & 3.160 & 1.730 & 1.280 & 1.360 & 1.600 & 0.770 \\
\hline $\begin{array}{l}\text { Inoculated with Bradyrizobium } \\
\text { japonicum USDAHH303+25\% } \\
\text { Nitrogen fertilizer }\end{array}$ & 3.370 & 3.540 & 3.140 & 1.760 & 1.275 & 1.340 & 1.520 & 0.790 \\
\hline $\begin{array}{l}\text { Inoculated with Bradyrizobium } \\
\text { japonicumiUK3407+25\%nitrogen } \\
\text { fertilier }\end{array}$ & 3.320 & 3.490 & 3.000 & 1.580 & 1.220 & 1.300 & 1.490 & 0.710 \\
\hline $\begin{array}{ll}\begin{array}{l}\text { Inoculated with } \\
\text { japonicum }\end{array} & \begin{array}{l}\text { Bradyrizobium } \\
\text { USDA118+25\% }\end{array} \\
\text { nitrogen fertilizer } & \\
\end{array}$ & 3.360 & 3.525 & 3.120 & 1.710 & 1.270 & 1.325 & 1.500 & 0.735 \\
\hline $\begin{array}{l}\begin{array}{l}\text { Inoculated with } \\
\text { japonicum } \\
\text { nitrogen fertilizer }\end{array} \\
\text { ARC500+25\% }\end{array}$ & 3.340 & 3.515 & 3.100 & 1.700 & 1.260 & 1.315 & 1.495 & 0.755 \\
\hline L.S.D.0.05 & 0.1628 & N.S & 0.0814 & 0.000 & N.S & 0.000 & 0.000 & 0.000 \\
\hline
\end{tabular}

after 60 days of sowing

\begin{tabular}{|c|c|c|c|c|c|c|c|c|}
\hline Character & Dry w & eight of st & hoot $(g$ & /plant) & Shoc & t $\mathrm{N}$-conte & nt $(\mathrm{mg} / \mathrm{p}$ & lant) \\
\hline Treatments Soybean cultivars & Clark & Crawford & Giza35 & Mc-call & Clark & Crawford & Giza35 & Mc-call \\
\hline $\begin{array}{l}\text { Uninoculated+(control)100\% } \\
\text { Nitrogen fertilizer }\end{array}$ & 18.700 & 24.900 & 19.200 & 14.000 & 364.667 & 498.00 & 412.800 & 274.400 \\
\hline $\begin{array}{l}\text { Inoculated with } \begin{array}{r}\text { Bradyrizobium } \\
\text { usda110+25\% }\end{array} \\
\text { japonicum } \\
\text { nitrogen fertilizer }\end{array}$ & 24.500 & 29.300 & 25.000 & 17.500 & 580.667 & 730.133 & 750.000 & 413.000 \\
\hline $\begin{array}{l}\text { Inoculated with Bradyrizobium } \\
\text { japonicum USDAHH303+25\% } \\
\text { Nitrogen fertilizer }\end{array}$ & 23.600 & 27.800 & 23.600 & 16.400 & 554.600 & 653.30 & 637.200 & 403.467 \\
\hline $\begin{array}{l}\text { Inoculated with Bradyrizobium } \\
\text { japonicumiUK3407+25\%nitrogen } \\
\text { fertilier }\end{array}$ & 20.500 & 25.333 & 20.700 & 14.500 & 440.800 & 543.967 & 486.467 & 326.267 \\
\hline $\begin{array}{ll}\text { Inoculated with } & \text { Bradyrizobium } \\
\text { japonicum } & \text { USDA118+25\% } \\
\text { nitrogen fertilizer } & \end{array}$ & 22.500 & 27.000 & 22.500 & 16.000 & 596.267 & 621.000 & 562.500 & 371.067 \\
\hline $\begin{array}{l}\begin{array}{l}\text { Inoculated with } \\
\text { japonicum } \\
\text { nitrogen fertilizer }\end{array} \\
\text { ARC500+25\% }\end{array}$ & 21.000 & 26.50013 & 21.500 & 15.000 & 472.500 & 596.267 & 522.500 & 353.400 \\
\hline L.S.D.0.05 & N.S & N.S & N.S & N.S & 132.5026 & N.S & 119.6508 & 74.808 \\
\hline
\end{tabular}


J. Agric. Sci. Mansoura Univ., 32 (2), February, 2007

$\begin{array}{lllllllll}1379-1380 & 1381 & 1382 & 1383 & 1384 & 1385 & 1386 & 1387 & 1389\end{array}$

$\begin{array}{lllllllll}1379-1380 & 1381 & 1382 & 1383 & 1384 & 1385 & 1386 & 1387 & 1389\end{array}$

13881908

13881908 